\title{
AKTUALISASI DEMOKRASI PANCASILA DALAM KEHIDUPAN BERBANGSA DAN BERNEGARA
}

\author{
Nur Rohim Yunus \\ Universitas Islam Negeri (UIN) Syarif Hidayatullah Jakarta \\ Email: nurrohimyunus@uinjkt.ac.id \\ Naskah diterima: 23 Oktober 2015, direvisi: 4 November 2015, disetujui: 20 November 2015
}

\begin{abstract}
Democracy, as well as a fundamental principle in virtually all countries, has also become principles in the country. Several typologies of democracy indicates a new pattern generated from the basic theory of democracy. Pancasila Democracy is essentially the norms regulating the conduct of the people's sovereignty and the running state government, in the political, economic, social, cultural, and defense, for every citizen of the Republic of Indonesia, both at central and regional levels. The concept of Pancasila democracy excavated from the original values of the society that developed in Indonesia. Pancasila Democracy is a middle path that must be addressed wisely because it is a unifying alternative between Indonesia multicultural society.

Keywords: Pancasila democracy, cultural values, Indonesia.

Abstrak

Demokrasi selain sebagai asas fundamental di hampir semua negara, demokrasi juga menjadi asas kenegaraan untuk penyelenggaraan suatu negara sebagai organisasi tertinggi. Terdapat beberapa tipologi demokrasi yang bervariatif dan menunjukkan adanya pola baru yang dihasilkan dari teori dasar demokrasi. Demokrasi Pancasila pada hakikatnya merupakan norma yang mengatur penyelenggaraan kedaulatan rakyat dan penyelenggaraan pemerintahan negara, dalam kehidupan politik, ekonomi, sosial budaya, dan pertahanan keamanan, bagi setiap warga negara Republik Indonesia, organisasi kekuatan sosial politik, organisasi kemasyarakatan, dan lembaga kemasyarakatan lainnya serta lembaga-lembaga negara baik di pusat maupun di daerah. Konsep demokrasi Pancasila digali dari nilai masyarakat asli Indonesia dengan nilai-nilai yang melekat kepadanya. Demokrasi Pancasila merupakan jalan tengah yang harus disikapi secara bijak karena merupakan alternatif pemersatu antara beragam latar belakang suku dan budaya masyarakat Indonesia.
\end{abstract}

Kata kunci: demokrasi Pancasila; nilai budaya; Indonesia.

Pengutipan: Yunus, N. R. (2015). Aktualisasi Demokrasi Pancasila dalam Kehidupan Berbangsa dan Bernegara. SOSIO DIDAKTIKA: Social Science Education Journal, 2(2), 2015, 156-166. doi:10.15408/sd.v2i2.2815.

Permalink/DOI: http://dx.doi.org/10.15408/sd.v2i2.2815 


\section{A. Pendahuluan}

Demokrasi sebagai suatu sistem telah menjadikan alternatif dalam berbagai tatanan aktivitas bermasyarakat dan bernegara di beberapa negara. Alasan menjadikan demokrasi sebagai sistem bermasyarakat dan bernegara dikarenakan hampir semua negara di dunia ini telah menjadikan demokrasi sebagai asas fundamental. Selain demokrasi dijadikan sebagai asas kenegaraan, secara esensial telah memberikan arah bagi peranan masyarakat untuk menyelenggarakan negara sebagai organisasi tertingginya, sehingga diperlukan pengetahuan dan pemahaman yang benar pada warga masyarakat tentang demokrasi.

Demokrasi dalam sejarah peradaban dianggap sudah mulai muncul sejak zaman Yunani Kuno. Capaian praktis dari sejak Demokrasi Yunani adalah munculnya apa yang disebut "negara kota (polis)". Polis adalah bentuk demokrasi pertama. Pericles dalam bukunya yang terkenal, Funeral Oration, menyatakan bahwa pemerintahan Athena disebut demokrasi karena administrasinya berada di tangan banyak pihak. Demikian pula ahli drama Aeschylus menyimpulkan bahwa tidak ada pemerintahan di Athena karena rakyat adalah pemerintah. ${ }^{1}$

Demokrasi berasal dari bahasa Latin demos (rakyat) dan kratos (pemerintahan), selalu diartikan sebagai pemerintahan dari, oleh, dan untuk rakyat. Istilah demokratia mulai dipakai di Athena sekitar pertengahan abad ke-5 M.

Pada abad ke-7 dan ke-6 SM, demos tidak mencakup massa rakyat. Namun, setelah pertengahan abad ke-5 SM, demokratia tampaknya telah digunakan pada umumnya dengan pengertian yang telah dimilikinya sampai sekarang ini, yaitu dengan pengertian "pemerintahan oleh rakyat".

Abraham Lincoln (1808-1865) adalah Presiden Amerika Serikat (AS) yang ke-16, yang pernah mengatakan bahwa demokrasi adalah pemerintahan dari rakyat, oleh rakyat, dan untuk rakyat. Demokrasi diakui banyak orang dan negara sebagai sebuah sistem nilai kemanusiaan

\footnotetext{
1 Henry J. Schmandt, Ahmad Baidlowi, Imam Bahehaqi, Kamdani, Filsafat Politik: Kajian Historis dari Zaman Yunani Kuno Sampai Zaman Modern (Jakarta: Pustaka Pelajar, 2002), h. 37.

2 Robert A. Dahl, Demokrasi dan Para Pengkeritiknya (Jakarta: Yayasan Obor Indonesia, 1992), h. 158
}

yang paling menjanjikan masa depan umat manusia yang lebih baik dari saat ini. Meskipun demikian, penolakan terhadap domokrasi juga tak sedikit jumlahnya.

Demokrasi dalam arti formal yaitu demokrasi sebagai suatu sistem pemerintahan atau sistem politik dimana kedaulatan rakyat tidak dilaksanakan sendiri oleh rakyat, tetapi melalui wakil-wakil yang dipilihnya di lembaga perwakilan. Sedangkan demokrasi dalam arti material dapat disebut sebagai demokrasi sebagai asas, yang dipengaruhi oleh kultur, historis suatu bangsa, sehingga dikenal demokrasi konstitusional, demokrasi rakyat dan demokrasi Pancasila. $^{3}$

\section{B. Tipologi Demokrasi}

Demokrasi memiliki makna yang variatif, karena bersifat interpretatif. Setiap penguasa negara berhak mengklaim negaranya sebagai demokratis meskipun nilai yang dianut atau praktik politik kekuasaannya amat jauh dari prinsip-prinsip dasar demokrasi. Karena sifatnya yang interpretatif itu, dikenal berbagai tipologi demokrasi, yaitu: Demokrasi Langsung, Demokrasi Konstitusional, Demokrasi Borjuis, Demokrasi Rakyat (Proletar), Demokrasi Perwakilan Liberal.

Pertama; Demokrasi Langsung. Demokrasi langsung adalah suatu kondisi ketika keseluruhan warga negara dengan nyata ikut serta dalam permusyawaratan untuk menentukan kebijaksanaan umum atau undang-undang, seperti yang dilaksanakan di zaman Yunani kuno. Demokrasi tidak langsung dilaksanakan dengan sistem perwakilan.

Tipe demokrasi ideal diwujudkan dalam derajat yang berbeda-beda melalui konstitusi yang berbeda-beda pula. Demokrasi langsung adalah demokrasi dengan derajat relatif paling tinggi. Demokrasi langsung ditandai dengan fakta pembuatan Undang-Undang (UU), dan juga fungsi eksekutif dan yudikatif yang utama, dijalankan oleh rakyat di dalam pertemuan akbar atau rapat umum. Pengorganisasian semacam ini hanya dapat dilakukan dalam masyarakat-

\footnotetext{
3 Bagir Manan, Kedaulatan Rakyat, Hak Asasi Manusia dan Negara Hukum (Jakarta: Gaya Media Pratama, 1996), h. 199.
} 
masyarakat kecil dan di bawah kondisi-kondisi sosial yang sederhana. ${ }^{4}$

Di dalam demokrasi langsung, seperti pada suku-suku bangsa Jerman dan Romawi Kuno, prinsip demokrasi sangat terbatas. Tidak semua warga masyarakat mempunyai hak untuk turut serta dalam pembahasan dan keputusan-keputusan dari majelis rakyat. Anakanak, kaum wanita, dan budak (apabila ada perbudakan) tidak memiliki hak politis. Saat ini hanya konstitusi-konstitusi dari sejumlah daerah bagian Swiss yang kecil-kecil yang memiliki karakter demokrasi langsung.

Aristoteles dipandang sebagai penyokong pemerintahan (kratos) oleh demos atau rakyat banyak. Akan tetapi, Plato mengkritik pandangan ini, karena sistem demokrasi mengabaikan mereka yang terdidik. Plato lebih mendukung suatu pemerintahan yang dipimpin oleh kelompak kecil penguasa dengan persetujuan banyak orang. Sedikit orang yang berkuasa menurutnya harus pandai, berpendidikan, dan kaya.

Negara kota Athena, yang diperintah oleh gubernur tidak membedakan antara negara dan masyarakat. Warga negara mempunyai fungsi sekaligus sebagai subjek dari kekuasaan politik dan pembuat peraturan dan regulasi. Rakyat (demos) terlibat dalam fungsi-fungsi legislatif dan yudikatif karena rakyat berpartisipasi secara langsung dalam urusan negara.

Syarat utama sistem ini antara lain adalah komitmen terhadap prinsip civic virtue, yaitu dedikasi terhadap negara kota republik dan penundukan kehidupan pribadi pada kepentingan umum dan masyarakat. Warga dapat memenuhi kebutuhannya dan hidup secara terhormat hanya di dalam dan melalui polis.

Kelemahan dari sistem ini adalah masih adanya sebagian rakyat yang disingkirkan, seperti kaum wanita dan para budak. Sistem ini diberlakukan karena jumlah masyarakatnya kecil atau disebut masyarakat yang bisa saling tatap muka dan masih memiliki budaya berbicara (bukan budaya tulis). Namun, model ini mengalami kemunduran terutama karena

Kelsen, Hans, Teori Hukum Murni (Jakarta: Rimdi Pers, 1995), h. 288. kemunculan rezim militer dan oligarkhi Roma yang kuat, yang terbukti lebih bertahan lama. Kemerosotan itu juga dilihat karena civic virtue yang dianggap menopang sistem itu ternyata sangat rentan terhadap manipulasi dan bergantung hanya pada keterlibatan salah satu dari kelompok utama saat itu, yaitu rakyat, aristokrasi, atau monarki.

Kedua; Demokrasi Konstitusional. Demokrasi konstitusional merupakan demokrasi yang terbatasi oleh aturan atau konstitusi. Pemerintah yang demokratis adalah pemerintah yang terbatasi kekuasaannya dan tidak dibenarkan untuk bertindak sewenang-wenang terhadap warga negaranya. Konstitusi memberikan batasan-batasan terhadap posisi dan peran atau wewenang pemerintah. Oleh karenanya, sering dinamakan pula sebagai "pemerintahan yang berdasarkan konstitusi". Jadi, constitutional government sama dengan limited government atau restrained government. ${ }^{5}$

Kewibawaan demokrasi konstitusional tergantung pada bagaimana konstitusi dihormati, terutama oleh pemerintah dan lembaga-lembaga pemerintahan (eksekutif, legislatif, dan yudikatif). Jika pemerintahan tak mematuhi hukum, demokrasi akan dilanggar dan terancam akan dilecehkan oleh masyarakat karena pemerintah tak mampu memberi contoh. Ketika konstitusi tidak ditegakkan oleh pemerintah, masyarakat juga tidak patuh pada aturan hukum sehingga demokrasi ditegakkan tanpa aturan di kalangan rakyat dengan cara menyalurkan tuntutan melalui tindakantindakan anarkis.

Hal ini menguatkan pandangan politik legalistis bahwa pusat dari bersatunya umat manusia dalam bentuk suatu negara adalah karena negara diatur oleh hukum yang memiliki daya ikat untuk menjadi rambu-rambu bersama. Demokrasi konstitusional akan menjadi masalah ketika berubah menjadi demokrasi yang bersifat liberal. Karena peran pemerintah dalam politik terbatas, hal ini memungkinkan kekuatan masyarakat sipil menguat.

Ketiga; Demokrasi Borjuis. Demokrasi Borjuis sebagaimana demokrasi rakyat merupakan

\footnotetext{
5 Miriam Budiardjo, Dasar-Dasar Ilmu Politik. (Jakarta: Gramedia Pustaka Utama, Cet ketiga, 2008), h. 52.
} 
bentuk demokrasi yang memuat cara pandang kelas. Demokrasi borjuis didasarkan pada kepemilikan pribadi atas alat-alat produksi, yang terkonsentrasi di tangan sedikit orang saja. Sehingga terjadi ketimpangan sosial di masyarakat.

Demokrasi model ini menyelubungi karakter kelas masyarakat kapitalis. Artinya secara formal, semua orang diakui mempunyai hak yang sama, sedangkan rakyat secara nyata tidak memiliki. Dampaknya, krisis sosial pun makin tajam dan demokrasi borjuis dikecam. Kekuasaan kapital monopoli sangat kuat dan selalu tegar menghadapi tuntutan kelas buruh. Bahkan, hak-hak yang telah diperjuangkan dengan susah payah (misalnya, kenaikan upah minimum) malah diinjak-injak lagi. Dari situasi seperti ini melahirkan sistem kediktatoran (fasis). Namun, hal ini tidak terjadi di negaranegara penganut demokrasi borjuis, karena kelas pekerja dapat mengorganisasi serta mewakili kepentingan (interest) mereka.

Keempat; Demokrasi Rakyat (Proletar). Demokrasi rakyat ini disebut juga demokrasi proletar, marxis-komunis, atau demokrasi Soviet. Tokoh aliran ini adalah Karl Marx. Masyarakat yang dicita-citakan adalah komunis, masyarakat yang tidak memiliki kelas sosial. Manusia dibebaskan dari keterikatan kepada kepemilikan pribadi. Negara dalam hal ini bukanlah lembaga di atas masyarakat yang mengatur masyarakat tanpa pamrih, melainkan alat dalam tangan kelas-kelas atas untuk mengamankan kekuasaan mereka. ${ }^{6}$

Untuk mencapai masyarakat itu, perlu jalan paksaan dari jalan kekuasaan. Menurut Kranenburg yang dikutip Miriam Budiardjo, ${ }^{7}$ dalam demokrasi Soviet ini terdapat perilaku mendewa-dewakan pimpinan.

Menurut Miriam Budiardjo, komunis tidak hanya merupakan sistem politik, tetapi juga mencerminkan gaya hidup yang berdasarkan nilai-nilai tertentu, seperti gagasan monoisme menolak adanya golongan-golongan; gagasan persatuan berakibat adanya kesadaran mau dipaksa dan oposisi ditindas; gagasan

\footnotetext{
6 Franz Magnis Suseno, Pemikiran Karl Marx: Dari Sosialisme Utopis ke Perselisiban Revisionism (Jakarta: Gramedia Pustaka Utama, 2005), h. 120.

7 Miriam Budiardjo, Dasar-Dasar Ilmu Politike (Jakarta: Gramedia Pustaka Utama, Cet. ketiga, 2008), h.77.
}

menjadikan negara sebagai alat untuk mencapai komunisme; kekerasan dipandang sebagai alat yang sah. ${ }^{8}$

Akan tetapi, ada perbedaan antara demokrasi sosialis dan demokrasi komunis. Kaum sosialis (sosialisme demokrasi) tidak menginginkan demokrasi satu partai seperti kaum komunis. Namun, kesamaannya adalah bahwa kaum sosialis juga menegaskan pentingnya demokrasi ekonomi, ketika alatalat produksi dan sumber-sumber ekonomi tak boleh dikuasai sedikit orang dan negara juga harus berperan dalam mengatur ekonomi rakyatnya, mengontrol, dan membatasi peran swasta (kapitalis) dalam perekonomian. Jadi, dalam demokrasi sosialistik, alat-alat produksi merupakan milik bersama. Maka interest pribadi kemudian sama dengan interest negara. Akan tetapi, tak perlu partai politik hanya satu, untuk menciptakan keseimbangan kekuatan dan menjamin kebebasan politik dan pluralisme kebudayaan.

Sedangkan, dalam demokrasi komunis, dalam rangka memperkuat dukungan massa untuk menghancurkan pengisap lama, pimpinan partai marxis-leninis atau marxismaois yang sadar kelas membentuk diktator proletariat. Demokrasi komunis dianggap sebagai demokrasi untuk mencapai tingkatan yang tertinggi. Demokrasi ini dibentuk berdasarkan undang-undang, yang mengawali tercapainya masyarakat tanpa kelas. Seluruh kegiatan sosial dan keharmonisan masyarakat merupakan realitas sosial. Dengan kata lain, dalam demokrasi realis, semua rakyat diajak, baik dalam proses perencanaan, pengaturan, maupun pelaksanaan - yang bertujuan agar kepribadian rakyat dapat berkembang optimal.

\section{Kelima; Demokrasi Perwakilan Liberal.} Ciri demokrasi tidak langsung atau perwakilan adalah suatu demokrasi ketika fungsi legislatif dijalankan oleh sebuah parlemen yang dipilih oleh rakyat, dan fungsi eksekutif dan yudikatif dijalankan oleh pejabat-pejabat yang juga dipilih melalui pemilihan umum (pemilu). Banyak konstitusi demokratis secara tegas menetapkan kebebasan para wakil dan para pemilihnya. Kebebasan para wakil dari pemilihnya ini adalah

\footnotetext{
8 Miriam Budiardjo, ibid, h.77
} 
ciri khas demokrasi modern.

Kebebasan hukum yang dimiliki orang yang dipilih dari pemilihnya tidak sama dengan perwakilan hukum. Pernyataan bahwa rakyat diwakili oleh parlemen berarti rakyat tidak dapat melaksanakan kekuasaan legislatif secara langsung atau kekuasaan dijalankan melalui wakilnya.

Perkembangan sistem demokrasi Athena dan Roma menunjukkan apakah partisipasi yang luas dari seluruh warga ataukah suatu sistem perwakilan lebih penting. Dalam perkembangannya, teori-teori demokrasi liberal dengan kedaulatan negara mendapat tempat yang kuat, dan pada saat yang sama juga berkembang pembatasan terhadap kekuasaan.

Demokrasi murni yang berarti masyarakat dengan jumlah penduduk kecil mengatur dan mengelola pemerintahan selalu tidak toleran, tidak adil, dan tidak stabil. Sebaliknya, pemerintahan perwakilan mengatasi ekses demokrasi murni ini karena pemilihan yang akan teratur memaksa adanya penjelasan terhadap isu-isu masyarakat dan mereka yang terpilih dan yang bertahan dalam proses politik boleh jadi merupakan orang yang sangat kompeten dan mampu menjelaskan serta menghasilkan kepentingan sesungguhnya dari negara mereka.?

Negara perwakilan menurut Madison sebagaimana dikutip David Held ${ }^{10}$ mempunyai mekanisme untuk mengagregasi kepentingankepentingan individu dan melindungi hakhak mereka. Dalam negara yang demikian, dia percaya keamanan individu dan propertinya akan dijaga dan politik dapat dibuat sesuai dengan tuntutan dan ambisi negara-negara besar yang memiliki pola perdagangan, ekonomi, dan hubungan internasional yang kompleks.

Sejalan dengan Madison, Bentham mendukung demokrasi perwakilan yang dapat mengamankan anggotanya dari penindasan beberapa fungsionaris yang berkuasa. Pemerintahan demokratis menurutnya melindungi warga negara dari penggunaan kekuasaan secara despotik, baik oleh monarki,

\footnotetext{
9 David Held, Prospects for Democracy, North, South, East, West (Cambridge: Polity Press and Blacwell, 1994), h.18

10 David Held, ibid, h.19.
}

aristokrasi, ataupun kelompok-kelompok lain. ${ }^{11}$

Negara perwakilan menjadi wasit ketika para individu memperjuangkan kepentingan mereka dengan mengikuti aturan kompetisi ekonomi dan pertukaran bebas. Pemilihan bebas dan pasar bebas keduanya penting berdasarkan asumsi dasar bahwa barang kolektif dapat diwujudkan secara memadai dalam kehidupan hanya jika individu-individu berinteraksi melalui pertukaran kompetitif dengan intervensi negara yang minimal.

Akan tetapi, jika balik peran "negara minimal" ini, yaitu wilayah dan kekuasaannya perlu dibatasi dengan ketat, masih ada komitmen kuat bagi perlunya intervensi negara pada bidang-bidang tertentu, yaitu untuk mengatur perilaku pembangkang dan membentuk kembali hubungan sosial dan lembaga-lembaga bila terjadi kegagalan dalam persaingan laissez-fairu, ketika kebahagiaan terbesar dari orang banyak tidak tercapai. ${ }^{12}$

Teori demokrasi perwakilan ini mengubah secara mendasar referensi pemikiran demokrasi ketika perdebatan tentang jumlah warga yang harus terlibat dalam demokrasi terpecahkan dan demokrasi perwakilan dianggap pemerintahan yang layak dan bertanggung jawab, dan stabil untuk negara-negara bangsa yang bermunculan.

Dari kelima tipologi demokrasi tadi, negara Indonesia lebih mengadopsi demokrasi tidak langsung atau perwakilan. Tetapi model demokrasi yang digunakan lebih didasarkan kepada kultur dan budaya masyarakat Indonesia yang bergantung pada ideologi Pancasila, sehingga demokrasi yang dikenal adalah Demokrasi Pancasila.

\section{Demokrasi Pancasila dalam Konsep dan Teori Bernegara Indonesia}

Demokrasi Pancasila merupakan demokrasi yang didasarkan pada asas kekeluargaan dan kegotongroyongan yang ditujukan kepada kesejahteraan rakyat, yang mengandung unsur-unsur berkesadaran religius, kebenaran, kecintaan dan budi pekerti luhur, berkepribadian 
Indonesia dan berkesinambungan. ${ }^{13}$

Dalam demokrasi Pancasila, sistem pengorganisasian negara dilakukan oleh rakyat sendiri atau dengan persetujuan rakyat. ${ }^{14}$ Kebebasan individu dalam demokrasi pancasila tidak bersifat mutlak, tetapi harus diselaraskan dengan tanggung jawab sosial. ${ }^{15}$

Keuniversalan cita-citademokrasidipadukan dengan cita-cita hidup bangsa Indonesia yang dijiwai oleh semangat kekeluargaan, sehingga tidak ada dominasi mayoritas atau minoritas. ${ }^{16}$

Demokrasi Pancasila pada hakikatnya merupakan norma yang mengatur penyelenggaraan kedaulatan rakyat dan penyelenggaraan pemerintahan negara, dalam kehidupan politik, ekonomi, sosial budaya, dan pertahanan keamanan, bagi setiap warga negara Republik Indonesia, organisasi kekuatan sosial politik, organisasi kemasyarakatan, dan lembaga kemasyarakatan lainnya serta lembaga-lembaga negara baik di pusat maupun di daerah.

Demokasi Pancasila ${ }^{17}$ memiliki prinsipprinsip yang berlaku, seperti:

1) Kebebasan atau persamaan (Freedom/ Equality). Kebebasan/persamaan adalah dasar demokrasi. Kebebasan dianggap sebagai sarana mencapai kemajuan dan memberikan hasil maksimal dari usaha orang tanpa pembatasan dari penguasa. Dengan prinsip persamaan semua orang dianggap sama, tanpa dibedabedakan dan memperoleh akses dan kesempatan bersama untuk mengembangkan diri sesuai dengan potensinya. Kebebasan yang dikandung dalam demokrasi Pancasila ini tidak berarti Free Fight Liberalism yang tumbuh di Barat, tapi kebebasan yang tidak mengganggu hak dan kebebasan orang lain.

2) Kedaulatan Rakyat (people's Sovereignty). Dengan konsep kedaulatan rakyat, hakikat kebijakan yang dibuat adalah kehendak rakyat dan untuk kepentingan rakyat. Mekanisme

\footnotetext{
13 Lihat Mohammad Hatta,"Indonesia Merdeka" dalam karya lengkap Bung Hatta.Buku I: Kebangsaan dan Kerakyatan (Jakarta: Penerbit LP3ES, 1998), h. 87

14 Pikiran dan Gagasan Adnan Buvung Nasution, Demokrasi Konstitusional (Jakarta; Kompas, 2010), h. 3-4

15 Yudi Latif, Negara Paripurna; Historisitas, Rasionalitas dan Aktualitas Pancasila (Jakarta; Pustaka Gramedia, 2011), h. 383.

16 Yudi Latif, Ibid, h. 250

17 Jimly Asshiddiqie, Hukum Tata Negara \& Pilar-Pilar Demokras (Jakarta; Sinar Grafika, 2011), h. 198-234
}

semacam ini akan mencapai dua hal; yaitu, kemungkinan terjadinya penyalahgunaan kekuasaan sangatlah kecil, dan kepentingan rakyat dalam tugas-tugas pemerintahan lebih terjamin. Perwujudan lain dari konsep kedaulatan adalah adanya pengawasan oleh rakyat. Pengawasan dilakukan karena demokrasi tidak mempercayai kebaikan hati penguasa.

3) Pemerintahan yang terbuka dan bertanggung jawab yang memiliki prinsipprinsip

a) Dewan Perwakilan Rakyat yang representatif. b) Badan kehakiman/peradilan yang bebas dan merdeka. c) Pers yang bebas, d) Prinsip Negara hukum, e) Sistem dwi partai atau multi partai. f) Pemilihan umum yang demokratis. g) Prinsip mayoritas. h) Jaminan akan hak-hak dasar dan hak-hak minoritas.

Di Indonesia, prinsip-prinsip demokrasi telah disusun sesuai dengan nilai-nilai yang tumbuh dalam masyarakat, meski harus dikatakan baru sebatas demokrasi prosedural, dalam proses pengambilan keputusan lebih mengedepankan voting ketimbang musyawarah untuk mufakat, yang sejatinya merupakan azas asli demokrasi Indonesia. (bukankah voting itu asas asli demokrasi liberal, jadi apa tidak berkebalikan). Praktek demokrasi ini tanpa dilandasi mental state yang berakar dari nilainilai luhur bangsa merupakan gerakan omong kosong belaka.

Ada beberapa unsur demokrasi yang dikemukakan oleh para Ahli di antaranya adalah: ${ }^{18}$

1) Menurut Sargen, Lyman Tower (1987), unsur demokrasi meliputi keterlibatan rakyat dalam mengambil keputusan politik, tingkat persamaan hak antarmanusia, tingkat kebebasan dan kemerdekaan yang dimiliki oleh warga Negara, sistem perwakilan dan sistem pemilihan ketentuan mayoritas.

2. Afan Gaffar (1999), unsur demokrasi meliputi akuntabilitas, rotasi kekuasaan, rekruitmen politik yang terbuka, pemilihan umum, dan hak-hak dasar.

18 Jimly Asshiddiqie, Ibid, h. 243-244 
3) Menurut Marriam Budiardjo (1977), terdapat beberapa unsur demokrasi, yaitu perlunya dibentuk lembaga-lembaga demokrasi untuk melaksanakan nilainilai demokrasi, yaitu pemerintahan yang bertanggung jawab, Dewan Perwakilan Rakyat, organisasi politik, pers dan media massa, serta peradilan yang bebas.

4) Menurut Frans Magnis Suseno(1997), menyebutkan ada lima gugus ciri hakiki Negara demokrasi. Kelima gugus demokrasi tersebut adalah negara hukum, pemerintahan di bawah kontrol nyata masyarakat, pemilihan umum yang bebas, prinsip mayoritas dan adanya jaminan terhadap hak-hak demokrasi.

\section{Upaya Aktualisasi Demokrasi Pancasila di Indonesia}

Sistem ketatanegaraan yang dianut oleh Undang-Undang Dasar 1945 adalah negara demokrasi konstitusional, dengan menganut asas demokrasi Pancasila. Dalam aktualisasinya, Demokrasi Pancasila didasarkan pada Pembukaan Undang Undang Dasar 45 alinea ke 4, yaitu kerakyatan yang dipimpin oleh hikmat kebijaksanaan dalam permusyawaratan/ perwakilan, yang mengandung semangat ketuhanan yang maha esa, kemanusiaan yang adil dan beradab, persatuan Indonesia, dan keadilan sosial bagi seluruh rakyat Indonesia.

Demokrasi Pancasila juga diartikan sebagai demokrasi yang dihayati oleh bangsa dan negara Indonesia yang dijiwai dan diintegrasikan oleh nilai-nilai luhur Pancasila. Dalam menganut asas demokrasi Pancasila, sistem pengorganisasian negara dilakukan oleh rakyat sendiri atau dengan persetujuan rakyat, dimana keluhuran manusia sebagai makhluk Tuhan dalam bidang politik, ekonomi, sosial budaya dan pertahanan keamanan diakui, ditaati dan dijamin atas dasar kenegaraan Pancasila.

Pemerintah berdasarkan atas demokrasi konstitusional tidak bersifat absolutisme (kekuasaan yang tidak terbatas). Konstitusi di sini diartikan dalam arti luas, sebagai living constitution, baik yang tertulis yang disebut
Undang-Undang Dasar Negara Republik Indonesia Tahun 1945, maupun hukum dasar yang tidak tertulis (konvensi), seperti aturanaturan dasar yang timbul dan terpelihara dalam praktek penyelenggaraan negara meskipun tidak tertulis.

Kedaulatan rakyat dengan sistem perwakilan atau demokrasi biasa disebut sistem demokrasi perwakilan (representative democracy) atau demokrasi tidak langsung (indirect democracy). Dalam praktek, pihak yang menjalankan kedaulatan rakyat itu adalah wakil-wakil rakyat yang duduk di lembaga perwakilan rakyat yang disebut parlemen. Agar wakil-wakil rakyat dapat bertindak atas nama rakyat, wakil-wakil rakyat itu harus ditentukan sendiri oleh rakyat, yaitu melalui pemilihan umum (general election). Dengan demikian, pemilihan umum itu tidak lain merupakan cara yang diselenggarakan untuk memilih wakil-wakil rakyat secara demokratis. ${ }^{19}$

Secara ideal pemilihan umum bertujuan agar terselenggaranya perubahan kekuasaan pemerintahan secara teratur dan damai sesuai dengan mekanisme yang dijamin oleh konstitusi. ${ }^{20}$

Tradisi berpikir bebas atau kebebasan berpikir (freedom of expression) itu pada gilirannya mempengaruhi tumbuh kembangnya prinsip-prinsip kemerdekaan berserikat atau berorganisasi (freedom of association) dan kemerdekaan berkumpul (freedom of assembly) dalam dinamika kehidupan masyarakat demokratis yang bersangkutan. ${ }^{21}$

Ismail Sunny menyatakan, Pemilihan umum adalah suatu kepastian dan suatu lembaga yang sangat vital untuk demokrasi. Suatu pemilihan yang bebas berarti bahwa dalam jangka waktu tertentu rakyat akan mendapat kesempatan untuk menyatakan hasratnya terhadap garisgaris politik yang harus diikuti oleh negara dan masyarakat terhadap orang-orang yang harus melaksanakan kebijaksanaan itu. ${ }^{22}$

\footnotetext{
19 Jimly Asshiddiqie, Pengantar Ilmu Hukum Tata Negara (Jakarta: Rajawali Press, 2009), h. 414.

20 Dede Mariana dan Caroline Paskarina, Demokrasi dan Politike Desentralisasi (Yogyakarta: Graha Ilmu, 2008), h. 5.

21 Jimly Asshiddiqie, Kemerdekaan Berserikat, Pembubaran Partai Politik. dan Mabkamah Konstitusi (Jakarta: Konpress, 2005), h. 711.

22 Ismail Sunny, Mekanisme Demokrasi Pancasila (Jakarta: Aksara Baru, 1984), h.21
} 
Pasal 22 ayat (1) UUDNRI Tahun 1945 menyebutkan bahwa, Pemilihan Umum dilaksanakan secara langsung, umum, bebas, rahasia, jujur dan adil setiap lima tahun sekali. Ada dua manfaat yang sekaligus sebagai tujuan atau sasaran langsung yang hendak dicapai dengan pelaksanaan pemilu yaitu, pembentukan atau pemupukan kekuasaan yang otoritas dan mencapai tingkat keterwakilan politik (political representativeness).

Selain itu Pemilu juga merupakan salah satu hak asasi warga negara yang sangat prinsipil, karena dalam pelaksanaan hak asasi adalah suatu keharusan pemerintah untuk melaksanakan pemilu. Oleh karena itu, pemilu adalah suatu syarat yang mutlak bagi negara demokrasi untuk melaksanakan kedaulatan rakyat. ${ }^{23}$

Hal ini merupakan perwujudan dari hak asasi manusia. Dalam pasal 28D ayat (3) berbunyi, Setiap warga negara berhak memperoleh kesempatan yang sama dalam pemerintahan. Pengertiannya, setiap orang memiliki hak untuk memilih dan dipilih dalam penyelenggaraan pemerintahan.

Pemilihan umum pada dasarnya memiliki empat fungsi utama yakni, pembentukan legitimasi penguasa, pembentukan perwakilan politik rakyat, sirkulasi elite penguasa, dan pendidikan politik. ${ }^{24}$

Tujuan penyelenggaraan pemilihan umum (general election) pada pokoknya dapat dirumuskan menjadi empat, yaitu:

a. Untuk memungkinkan terjadinya peralihan kepemimpinan pemerintahan secara tertib dan damai.

b. Untuk memungkinkan terjadinya pergantian pejabat yang akan mewakili kepentingan rakyat di lembaga perwakilan.

c. Untuk melaksanakan prinsip kedaulatan rakyat, dan

d. Untuk melaksanakan prinsip hak-hak asasi warga negara. ${ }^{25}$

Pemilihan umum juga bertujuan untuk memungkinkan terjadinya peralihan

\footnotetext{
23 Moh. Kusnardi dan Harmaily Ibrahim, Pengantar Hukum Tata Negara Indonesia (Jakarta: Pusat Studi Hukum Tata Negara FHUI, 1978), h. 329.

24 Arbi Sanit, Partai, Pemilu dan Demokrasi (Jakarta: Pustaka Pelajar, 1997), h. 158.

25 Jimly Asshiddiqie, Pokok-Pokok Hukum Tata Negara Indonesia Pasca Reformasi (Jakarta: PT Bhuana Ilmu Populer Kelompok Gramedia, 2007), h. 754.
}

pemerintahan dan pergantian pejabat negara yang diangkat melalui pemilihan (elected public officials). Yang dimaksud di sini adalah pemilihan umum harus membuka kesempatan sama untuk menang atau kalah bagi setiap peserta pemilihan umum itu, karena pemilihan umum sejatinya adalah hak setiap orang sebagai warga negara. ${ }^{26}$

Tujuan ketiga dan keempat pemilihan umum adalah untuk melaksanakan kedaulatan rakyat dan melaksanakan hak asasi warga negara. Hak-hak politik rakyat untuk menentukan jalannya pemerintahan dan fungsi-fungsi negara dengan benar menurut UUDNRI 1945 adalah hak rakyat yang sangat fundamental. Karena itu, penyelenggaraan pemilihan umum, di samping merupakan perwujudan kedaulatan rakyat, juga merupakan sarana pelaksanaan hak asasi warga negara.

Pengaturan mengenai hak asasi manusia di bidang politik yang sangat berkaitan dengan pemilihan umum adalah ketentuan pasal 28E ayat (3) yang merumuskan bahwa, Setiap orang berbak atas kebebasan berserikat, berkumpul dan mengeluarkan pendapat. Kebebasan berserikat dan berkumpul dapat diwujudkan dalam bentuk keikutsertaan warga negara untuk berpartisipasi dalam partai politik yang diakui keberadaannnya olehperaturan perundang-undangan. Sedangkan kebebasan untuk mengeluarkan pendapat diwujudkan dalam bentuk keikutsertaan warga negara untuk menentukan wakil-wakilnya yang akan duduk dalam badan perwakilan rakyat maupun sebagai Presiden yang diwujudkan melalui pemilihan umum itu sendiri.

\section{E. Hubungan Demokrasi Pancasila dan Kebudayaan Asli Indonesia}

Konsep demokrasi pancasila digali dari nilai masyarakat asli Indonesia dengan nilai-nilai yang melekat kepadanya, seperti desa demokrasi, rapat kolektivisme, musyawarah mufakat, tolong-menolong dan istilah-istilah lain yang berkaitan dengan itu. Tujuannya, memberikan pendasaran empiris sosiologis tentang konsep demokrasi yang sesuai dengan sifat kehidupan masyarakat asli Indonesia, bukan sesuatu yang

26 Budiman B Sagala, Praketek. Sistem Ketatanegaraan Menurut UUD 1945 (Jakarta: Ghalia Indonesia, 1982), h. 67-68. 
asing yang berasal dari Barat dan dipaksakan pada realitas kehidupan bangsa Indonesia.

Masyarakat asli yang dimaksudkan di sini adalah bentuk kehidupan masyarakat yang sudah berlangsung di pulau-pulau di Nusantara sejak berabad-abad yang lalu dan yang tersusun dari satuan-satuan kehidupan yang terkecil yang berbeda-beda seperti desa di Jawa, nagari di Sumatra Barat, pekon di Lampung atau subak di Bali. Masyarakat asli ini memiliki seperangkat nilai mental dan moral yang bersifat homogen, struktural dan kolektif, yang kesemuanya memiliki sistem budaya sendiri dan berlangsung secara demokratis, yaitu demokrasi secara langsung sebagaimana terdapat di negaranegara kota di Yunani kuno 25 abad yang lalu. Proses metamorfosis nilai-nilai demokrasi yang digali dari kearifan budaya Indonesia tersebut mengalami beberapa periodisasi dalam proses implementasinya sebagai suatu keniscayaan.

Kebudayaan merupakan ruh dan jati diri bangsa dalam kehidupan bernegara, di mana tinggi rendahnya martabat bangsa sangat ditentukan oleh tinggi rendahnya budaya bangsa itu sendiri. Jati diri bangsa Indonesia sangat ditentukan oleh hasil proses aktualisasi nilainilai budaya bangsa dalam Negara Kesatuan Republik Indonesia. ${ }^{27}$ Pancasila sebagai budaya dan ideologi yang sedang men "sistem", harapannya adalah akan mampu menopang tuntutan demokrasi yang bertahap maju secara kultural-edukatif, dengan rujukan pola pikir budayawinya sendiri. Sistem ideologi yang mampu tumbuh dengan terbuka mengemban peningkatan kesadaran dan partisipasi politik dan ekonomi rakyat yang semakin tinggi dari waktu ke waktu, tanpa efek alienasi budaya, bahkan memperkuat wujud kebangkitan nasional Indonesia yang tahapannya semakin matang dan dewasa. Ini mengimplikasikan kebutuhan akan politik kebudayaan yang didasarkan pada Pancasila. Dengan lain kata, untuk menciptakan budaya bangsa yang berdasarkan pada nilainilai Pancasila diperlukan suatu rekayasa kebudayaan atau suatu strategi kebudayaan. ${ }^{28}$ Perlu disadari batas-batasnya serta kehati-hatian dalam menentukan caranya, sehingga strategi

\footnotetext{
27 Harian Kedaulatan Rakyat, 28 Juli 2004.

28 Sastraprateja, M. Pancasila Sebagai Ideologi dalam Kehidupan Budaya (Jakarta: Perum Percetakan Negara, 1992), h. 141.
}

budaya itu sendiri tidak justru menghasilkan sesuatu yang kontra-produktif atau bahkan bertentangan dengan prinsip-prinsip budaya demokrasi Pancasila yang hendak diterapkan. Dengan demikian dapat dihindarkan segala kecenderungan yang menjadikan Pancasila Ideologi totaliter.

Pendefinisian ideologi di sini tidak terlalu membedakan antara ideologi dan paham serta tidak membedakan ideologi yang bersifat murni atau tidak. Sebab menurut koran Pedoman yang terbit di tahun 1960 dengan mengutip pemikiran ahli politik Barat, ideologi yang benar-benar murni di dunia itu ada tiga yaitu liberalisme, sosialisme dan Islam. Walaupun sejatinya Islam bukan termasuk ideologi, karena bukan merupakan karya manusia. Pancasila merupakan contoh ideologi campuran, karena merupakan perpaduan dari berbagai unsur ideologi murni yaitu liberalisme dan sosialisme ditambah dengan nilai-nilai moral dan budaya Indonesia. Hal ini terbukti dengan kenyataan yang sama di dunia sekarang ini karena berkembang ideologi jalan ketiga (Third Way) yang merupakan kompromi atau campuran antara liberalisme dan sosialisme.

Alfian $^{29}$ mengatakan bahwa Pancasila sebagai ideologi dalam kehidupan demokrasi antara lain terletak pada kualitas yang terkandung di dalam dirinya. Di samping itu relevansinya terletak pada posisi komparatif terhadap ideologi-ideologi lain sehingga bangsa Indonesia yang meyakini, menghayati dan memahami mengapa Pancasila adalah ideologi untuk dipakai sebagai landasan dan sekaligus tujuan dalam membangun dirinya dalam berbagai kehidupan bermasyarakat, berbangsa dan bernegara, termasuk kehidupan politik.

Menurut Hatta, ${ }^{30}$ Pancasila sila Ketuhanan Yang Maha Esa menjadi dasar yang memimpin sila-sila yang lain. Seperti halnya sila kerakyatan atau demokrasi, Hatta yakin bahwa demokrasi akan hidup selama-lamanya di bumi Indonesia, sekalipun akan mengalami pasang naik dan pasang surut. Menurut Hatta, sumber demokrasi atau lebih tegasnya demokrasi sosial,

\footnotetext{
29 Alfian, Pancasila Sebagai Ideologi dalam Kehidupan Politik (Jakarta: Perum Percetakan Negara, 1990), h. 190.

30 Mohamad Hatta, Menuju Negara Hukum (Jakarta: Idayu Press, 1977), hlm.17.
} 
di Indonesia ada tiga; Pertama, sosialisme Barat yang membela prinsip-prinsip humanisme, dan prinsip ini juga dipandang sebagai tujuan. Kedua, ajaran Islam yang memerintahkan kebenaran dan keadilan Tuhan dalam bermasyarakat. Ketiga, pola hidup dalam bentuk kolektivisme sebagaimana terdapat di desa-desa di Indonesia. Ketiga sumber inilah yang akan menjamin kelestarian demokrasi di Indonesia, sehingga Hatta berkeyakinan bahwa demokrasi di Indonesia mempunyai dasar yang kukuh.

\section{F. Penutup}

Demokrasi yang terlahir dari adanya kedaulatan rakyat secara mutlak, ternyata mengalami metamorfose dan perubahan. Terutama pada saat berakulturasi dengan budaya masyarakat setempat yang ditempatinya. Tipologi demokrasi yang bervariatif menunjukkan adanya pola baru yang dihasilkan dari teori dasar demokrasi. Termasuk dalam hal ini Indonesia. Indonesia dengan kedaulatan rakyatnya kemudian menyerap kebudayaan aslinya untuk kemudian menjelma menjadi demokrasi tersendiri bernama demokrasi pancasila. Menyelesaikan pertikaian secara damai dan sukarela dengan membela prinsip-prinsip humanisme, menegakan keadilan di tengah keanekaragaman masyarakat, kolektivisme dan penggunaan paksaan sesedikit mungkin menjadikan contoh aktualisasi nyata demokrasi Pancasila dalam kehidupan berbangsa dan bernegara di Indonesia. Demokrasi Pancasila ini pun, mengalami banyak hambatan dan tantangan. Sebagian berupaya menerapkan dan sebagian lain menolak. Tetapi apa pun realita yang terjadi patut disadari, demokrasi pancasila merupakan jalan tengah yang harus disikapi secara bijak. Ia merupakan alternatif pemersatu antara beragama latar belakang suku dan budaya masyarakat Indonesia.

\section{G. Daftar Pustaka}

Alfian. (1990). Pancasila Sebagai Ideologi dalam Kebidupan Politik. Jakarta: Perum Percetakan Negara.
Asshiddiqie, Jimly. (2011). Hukum Tata Negara \& Pilar-Pilar Demokrasi. Jakarta: Sinar Grafika.

Asshiddiqie, Jimly. (2005). Kemerdekaan Berserikat, Pembubaran Partai Politik dan Mabkamah Konstitusi. Jakarta: Konpress.

Asshiddiqie, Jimly. (2009). Pengantar Ilmu Hukum Tata Negara. Jakarta: Rajawali Press.

Asshiddiqie, Jimly. (2007). Pokok-Pokok Hukum Tata Negara Indonesia Pasca Reformasi. Jakarta: PT Bhuana Ilmu Populer Kelompok Gramedia.

Budiardjo, Miriam. (2008). Dasar-Dasar Ilmu Politik. Jakarta: Gramedia Pustaka Utama, Cetakan ketiga.

Buyung N., Adnan. (2010). Pikiran dan Gagasan: Demokrasi Konstitusional. Jakarta: Kompas.

Dahl, Robert A. (1992) Demokrasi dan Para Pengkeritiknya. Jakarta: Yayasan Obor Indonesia.

Dede, Mariana dan Paskarina, Caroline. (2008). Demokrasi dan Politik Desentralisasi. Yogyakarta: Graha Ilmu.

Hatta, Mohammad. (1977). Menuju Negara Hukum. Jakarta: Idayu Press.

. (1998)."'Indonesia Merdeka" dalam karya lengkap Bung Hatta, Buku I: Kebangsaan dan Kerakyatan. Jakarta: Penerbit LP3ES.

Held, David. (1994). Prospects for Democracy, North, South, East, West. Cambridge: Polity Press and Blacwell.

Kelsen, Hans. (1995). Teori Hukum Murni. Jakarta: Rimdi Pers.

Kusnardi, Moh., dan Harmaily Ibrahim. (1978). Pengantar Hukum Tata Negara Indonesia. Jakarta: Pusat Studi Hukum Tata Negara FHUI.

Latif, Yudi. (2011). Negara Paripurna. Historisitas, Rasionalitas dan Aktualitas Pancasila. Jakarta: Pustaka Gramedia.

Manan, Bagir. (1996). Kedaulatan Rakyat, Hak Asasi Manusia dan Negara Hukum. Jakarta: Gaya Media Pratama. 
Sagala, Budiman B. (1982). Praktek Sistem Ketatanegaraan Menurut UUD 1945. Jakarta: Ghalia Indonesia.

Sanit, Arbi. (1997). Partai, Pemilu dan Demokrasi, Jakarta: Pustaka Pelajar.

Sastraprateja, M. (1992). Pancasila Sebagai Ideologi dalam Kehidupan Budaya. Jakarta: Perum Percetakan Negara.

Schmandt, Henry J., Baidlowi, Ahmad., Bahehaqi, I., Kamdani. (2002). Filsafat Politik: Kajian Historis dari Zaman Yunani Kuno Sampai Zaman Modern. Jakarta: Pustaka Pelajar.
Sunny, Ismail. (1984). Mekanisme Demokrasi Pancasila. Jakarta: Aksara Baru.

Suseno, Franz Magnis. (2005). Pemikiran Karl Marx: Dari Sosialisme Utopis ke Perselisihan Revisionism. Jakarta: Gramedia Pustaka Utama.

Surat Kabar:

Harian Kedaulatan Rakyat, 28 Juli 2004. 